\title{
The Role of Perceived Justice in Building Brand Trust
}

\author{
Faruk Anıl Konuk ${ }^{1}$ \\ ${ }^{1}$ Faculty of Business, Sakarya University, Sakarya, Turkey \\ Correspondence: Faruk Anıl Konuk, Department of Business Administration, Faculty of Business, Sakarya \\ University, Esentepe Campus, Sakarya, Turkey. E-mail: fkonuk@sakarya.edu.tr
}

Received: March 20, 2013 Accepted: March 27, 2013 Online Published: March 28, 2013

doi:10.5539/ijms.v5n2p154 URL: http://dx.doi.org/10.5539/ijms.v5n2p154

\begin{abstract}
The objective of this study is to examine the relationships between perceived justice, brand trust and switching costs. In this context, using convenience sampling, a survey was conducted on 427 complaining customers regarding with white goods. Structural equation modeling was used to test the proposed hypotheses. The results of the empirical study reveal that perceived justice dimensions are positively related to brand trust and switching costs. In addition, the findings also confirm positive relationship between brand trust and switching costs. At the end of this study, managerial implications are discussed.
\end{abstract}

Keywords: perceive justice, brand trust, switching costs, white goods

\section{Introduction}

In recent years, due to the technology development and diffusion, technology products are becoming similar based on their specifications and therefore, brands started to conduct different strategies in order to differentiate themselves in the marketplace. Regarding to this, in a fierce compettitve environment companies increasingly started to understand the importance of loyalty and maintaining long-term relationships with customers (Blodgett, Hill, \& Tax, 1997, p.185). In addition, evidence demonstrated that long-time customers are less price sensitive and tend to spend more thus, it is considered that cost of keeping customers are less than acquiring new ones (Hui and $\mathrm{Au}, 2001$, p.161). Moreover, past research demonstrated that effective complaint handling leads to long-term profitability (Reichheld \& Sasser, 1990; Johnson, 2001).

Most of the retailers recognize that complaints present an opportunity to redress product and service related problems and successful complaint handling process is considered one of the most important strategic tools for gaining competitive advantage in the marketplace (Blodgett et al., 1997, p.186). In this context, for retailers achieving brand trust is an important concept to differentiate their brands among competitors. For this aim one of the weapons those brands can benefit from is properly managed customer complaints. However, retailers cannot eliminate complaints about products or services despite precautions, they can successfully resolve the problems (Maxham III \& Netemeyer, 2002, p.239; Homburg \& Fürst, 2005, p.95; Kim, Kim, Kim \& 2009, p.51). On the other hand, Tax, Brown and Chandraskeran $(1998$, p.78) stated that "more than half of the customers dissatiffied with their complaint handling experience". In this regard, retailer have important role for creating brand trust with handling customer complaints successfully. In other words, retailers can play an important role in shaping customers trust perceptions about brands relating with the post-purchase evaluations including service recovery process.

In the service literature, perceived justice concept is widely used to understand customer evaluations of complaint handling process. In these studies, perceived justice dimensions were found as an antecedents of recovery satisfaction (Tax et al., 1998; de Matos, Rossi, Veiga \& Veira, 2009), overall satisfaction (Maxham III \& Netemeyer, 2002), company trust (Tax et al., 1998; Kau \& Loh, 2006; dos Santos \& Fernandes, 2008), word-of-mouth intentions (Maxham III and Netemeyer 2002; Blodgett et al., 1997; dos Santos \& Fernandes, 2008; Kau and Loh, 2006; Matos et al., 2009) and purchase intentions (Maxham III and Netemeyer, 2002). Moreover, in recent years some researchers have also investigated the relationships between positive and negative emotions and perceived justice dimensions (del Río-Lanza, Vazquez-Casilles \& Diaz-Martin, 2009; Schoefer \& Enew 2005, DeWitt, Nguyen, \& Marshall, 2008). Although these studies have helped to understand customers' evaluations of complaint handling process in different views, the effect of perceived justice on switching costs has not been explicitly considered and empirically analyzed in the context of durable goods. Past 
evidence also suggest that trust and switching cost as antecedents of behavioral intentions (Lam, Shankar, Eramili \& 2004; Yang \& Peterson, 2004; Wong, 2011; Fuentes-Blasco, Saura, \& Berenguer-Contri, 2010; Edward, George, \& Sarkar, 2010; Beerli, Martin, \& Quintana, 2004; Tung, Kuo, \& Kuo, 2011). Thus, understanding the effects of perceived justice on brand trust and switching costs is of great interest. Although, trust is considered a critical element for maintaining relationship between customer and a firm, there are few empirical studies revealing the direct effect of perceived justice on trust (Dewitt et al., 2008; dos Santos \& Fernandes, 2008). On the basis of these considerations, this study aims to fulfill this gap by analyzing the relationship between perceived justice, brand trust and switching costs. In other words, with this study it is aimed to shed new insight of the perceived justice which is an unexplored concept in the context of switching costs regarding with durable goods.

White goods were chosen for this research due to their high service component (Chiou and Droge, 2006, p.614) and the relationships between customers and the firm in the white goods market generally regarded as long-term (Ranawera \& Prabhu, 2003, p.376) and trust relevant (Chiou \& Droge, 2006, p.614) and most consumers are familier with them (Delgado Ballester \& Munuera-Alemán, 2005, p.189). As a result, this product category is suitable to understand the relationship between perceived justice and brand trust and switching costs.

The following of this paper is organized as follows. Firstly, perceived justice and brand trust concepts are defined and discussed how perceived justice contributes to brand trust and switching costs. According to this discussion, research model is proposed and hypotheses are suggested based on this model. Subsequently, under the research methodology section, data collection, measurement and descriptive statistics are presented. Consequently, results of this study are explained and compared to previous findings from the literature and implications are presented based on the empirical findings. In the last section, research limitations and some opportunities for future research are also also presented.

\section{Literature Review and Hypotheses Development}

In this section, perceived justice, brand trust and switching costs concepts are defined and hypotheses are proposed based on the previous literature. The proposed model was developed building on previous litetarure with seven hypotheses. In the model perceived justice is modeled as antecedent to brand trust and switching costs. The proposed model is depicted in Figure 1.

\subsection{Perceived Justice and Brand Trust}

Trust is one of the most important and fundamental concepts in the brand literature as it contributes to customer loyalty (Morgan \& Hunt, 1994; Matzler, Grabner-Kraüter, \& Bidmon, 2008; Chiou and Droge, 2006), brand equity (Delgado-Ballester and Manuera-Alemán, 2005), brand extension acceptance (Reast, 2005) and word-of-mouth intentions (dos Santos and Fernandes, 2008). Moorman, Deshpandé and Zaltman (1993, p.82), defined trust as "willingness to rely on a exchange partner in whom one has confidence. Within this context, Chaudhuri and Hollbrook (2001, p.82) defined brand trust as "the willingness of the average consumer to rely on the ability of the brand to perform its stated function". Brand trust has also been considered as a risk reducer relating with uncertain and complex purchase decisions (Matzler et al., 2008, p.155) which customers feel vulnerable (Chaudhuri \& Hollbrook 2001, p.82). In addition, reducing risk encourage customers to maintain relationships with the firm and enchance loyalty (dos Santos \& Fernandes, 2008, p. 226). Delgado-Ballester and Munuera-Alemán (2005, p.193) pointed out that "the the more positive experiences the consumers has with the brand the more trusting he or she is likey to become". In this context, with regards to the effects of perceived justice on brand trust, empirical evidence revealed positive relationship between these constructs (dos Santos and Fernandes, 2008; Dewitt et al., 2008).

Complaint handling is particularly vital for service-oriented firms (Tax et al. 1998, p.60). From a process perspective, complaint handling can be viewed as "a sequence of events in which a procedure, beginning with communicating the complaint, generates a process of interaction through which a decision and outcome occurs" (Tax et al., 1998, p.61). In other words, Brown, Barry and Gunst (1996, p.32) defined service recovery as "fixing or compensating for service failure". In addition, Hart, Heskett and Sasser (1990), emphasized the importance of the complaint handling process and concluded that "recovery is fundamental to service excellence and should therefore be regarded as an integral part of a service company's strategy". The concept of fairness or justice is has its roots in social psychology (Blodgett et al. 1997, p.188) and successfully used as a basis for understanding customers' evaluations of the complaint handling process (Maxham III \& Netemeyer, 2002; Kim et al., 2009). Justice theory emphasize that "customer evaluates a service recovery attempts as just or unjust." (Dewitt et al., 270). Service research highline customers' evaluations of service recovery process with three different aspects including interaction with firm staff, firms' procedures relating with handling complaints and outcomes of 
service recovery process (Maxham III \& Netemeyer, 2002; Tax et al., 1998). Based on the justice theory, these dimensions are referred as distributive, procedural and interactional justice.

Distributive justice describes "the fairness of the complaint outcome as customer perceives it" (Homburg \& Fürst, 2005, p.98). In other words, in a complaint process "distributive justice centers on the perceived fairness of the redress offered to consumers to resolve their problem" (Blodgett et al., 1997, p.188). Distributive justice outcomes represent refunds, discounts, changing the good or service and other forms of redress offered to customers following a product or service failure (Maxham III \& Netemeyer 2002, p.240; del Río-Lanza et al., 2009, p.776). In this study setting, when customers have complaints about white goods, their brand trust levels should be determined by the compliant outcomes including, refund, discount, and replace the white good with the new ones. Thus, the following hypothesis is proposed.

Hypothesis1: Distributive justice is positively relating to brand trust.

Procedural justice refers to the "perceived fairness of policies and procedures involving recovery effort" (Maxham III \& Netemeyer 2002, p.240). In other words procedural justice defined as "the perceived fairness of policies, procedures, andcriteria used by decision makers to arrive at the outcome of a dispute or negotiation" (Blodgett et al., 1997, p. 189). Procedural justice contruct includes the timeliness, reflective, responsiveness, and convenience of the complaint handling process, (Blodgett et al., 1997, p.189), accessibility, delay and flexibility to adopt to the consumers' recovery needs (del Rio-Lanza et al., 2009, p.776). When complaining customers seek for redress, they should evaluate company policies and procedures based on flexibility, timeliness responsiveness. Consequently, customer's evalauations may affect brand trust. As such, hypothesis 2 is posited.

Hypothesis 2: Prodecural justice is positively relating to brand trust.

Tax et al. (1998, p. 62) conceptualized interactional justice as "the perceived fairness of interpersonal treatment that people receive during the enactment of procedures." This justice dimension includes customer perceptions of employee emphaty, employee politeness and employee effort (Homburg \& Fürst, 2005, p.98). Tax et al. (1998, p.72), p.72) claimed that, the redress that delivered by rude employees and managers are appeared less valuable to complaining customers, on the other hand customers outcome evaluations can be positively supported by considerable effort by the employees. Fair interactional treatment in complaint handling that may lead to customers trust and complainers especially pay attention to courteouse and respectful treatment (dos Santos \& Fernandes, 2008, p.238). In other words, interpersonal relationships with the retailer staff and how they handle the problem may determine the brand trust evaluations. In this context, when consumer purchase a product from a retailer and have a problem after using it and return to the retailer with the aim of the redress, perceived justice may play a role for evaluating the brand in the customer side. Thus, it is expected that, interactional justice has positive effect on brand trust. Based on this line of reasoning, the following hypothesis is suggested.

Hypothesis 3: Interactional justice is positively relating to brand trust.

\subsection{Perceived Justice and Switching Costs}

As it was pointed out previously that, switching costs has been considered as an antecedent of behavioral intentions and researchers has integrated this concept into their proposed models in order to understand customers' past purchase behavior in a detailed way. Switching costs are "the costs that the consumer incurs by changing providers that they would not incur if they stayed with the current provider" (Lee, Lee \& Feick, 2001, p.36). In other words, perceived switching costs are consumers' perceptions of the time, money and effort associated with changing their current service providers (Jones, Mothersbaugh \& Baetty, 2000, p.262). As customers' perceived switching costs increase, their decision to switch their current supplier to another will be more difficult (Fuentes- Blasco et al., 2010, p.1841).

The main cause for customers switching behavior in the service sector is related to service failures and failed recoveries (de Matos et al., 2009, p.463; Keaveney, 1995; Dewitt et al., 2007, p.269). However, as it was mentioned previously, there is a lack of research revealing the relationship between perceived justice and switching costs. In this context, it is expected that when perceived justice of the complaining customers regarding with compliant handling process inceased their perceived switching costs may also be enchanced. In other words, for complaining customers perceived justice can be a switching barriers in terms of time, money and effort to end the current relationshipship with the firm. Hence, the following hypotheses are proposed.

Hypothesis 4: Distributive justice is positively relating to switching costs.

Hypothesis 5: Procedural justice is positively relating to switching costs.

Hypothesis 6: Interactional justice is positively relating to switching costs. 


\subsection{Brand Trust and Switching Costs}

Recent evidence revealed positive relationship between trust and switching costs (Yen et al., 2011; Konuk \& Konuk, 2012). In other words, brand trust can be attributed as a switching barrier by the customers. In this context, in the complaint handling process when customers trust to the brand after fair compliant resolution, their switching costs are expected to be increased. Thus, the following hypothesis is suggested.

Hypothesis 7: Brand trust is positively relating to switching costs.

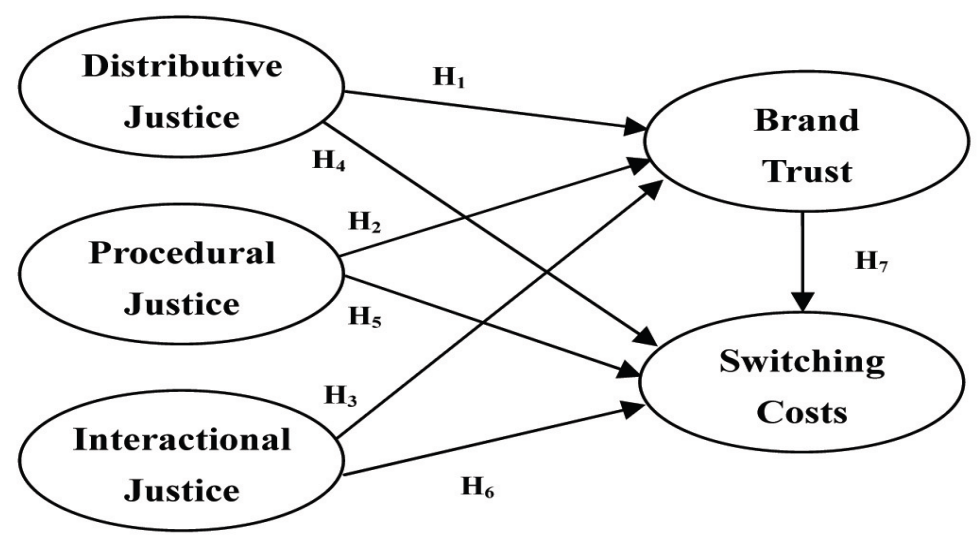

Figure 1. Proposed model

\section{Methodology}

In this section, data collection process and sampling procedure is explained. Subsequently, measurement of the relevant constructs is presented. Consequently, descriptive statistics of the sample is introduced.

\subsection{Data Collection and Sample}

By using convenience sampling, data were collected from 550 complaining customers using individually completed questionnaires during May-June 2012 from Istanbul which is the most populated city in Turkey. Because this study examines customers' compliant handling evaluations, it includes only those customers who have complained towards white goods and seek redress from the retailer. Thus, customers that had a problem with their white goods in the past and complained to the store were solicited to complete the questionnaires in a frame of a week. Complaining customers were requested to answer the questionnaires based on their recent complaint process in a frame of a week. A total of 550 questionnaires were distributed and collected from consumers in a frame of two weeks. Out of 550 customers, 452 of them returned the questionnaires, representing the response rate of $82 \%$. Of these, 25 questionnaires had to be excluded from the sample due to incomplete responses. Thus, 427 samples remained for the analysis.

Approximately, $56 \%$ of the respondents were female and $44 \%$ between the ages of $19-3042 \%$ the ages of. $31-40$ and predominantly married $(62 \%)$. In terms of educational levels, $69 \%$ obtained university degree. With regard to monthly family income about $37 \%$ of the respondents earned between $1001-3000$ TL and $24 \%$ between 3001-5000 TL.

\subsection{Measurement}

A cross-sectional survey design was used to assess customers' evaluations of their most recent service-related complaint. The survey instrument had two distinct parts. In the first part, statements measuring concepts of perceived justice, brand trust and switching costs were included. In the second part demographical questions of the respondents were asked including gender, maritial statues, education level and income.

Three item brand trust scale was adapted from Chaudhuri and Holbrook (2001) reflected the brand's trustworthiness, honesty and safety. Interactional justice, procedural justice and distributive justice dimensions were measured with four items respectively and adapted from Maxham III and Netemeyer's (2002) relevant scales. Interactional justice items accounted for store staff's courteous behavior, interest in solving customer's problem about the product. Procedural justice items represent the fairness of the policies and procedures and distributive justice items covered the fairness of the outcome of the recovery. In addition, switching costs were measured with three items from Wong (2011) and Lam et al. (2004). In order to achieve the face validity, two 
professionals and three academicians were consulted to assess the suitability of the scales (Edward et al., 2012). After this phase, prior to the manin field study, a pre-test was carried out with 25 respondents. On the basis of the respondent comments, limited numbers of scale items were slightly reworded in order to increase the understandability. All brand trust and justice items were measured by 5-point Likert-type scales were anchored with "strongly disagree to "strongly agree". All measurement items are presented in Table 1.

Table 1. Items and measurement model results

\begin{tabular}{|c|c|}
\hline Constructs & $\begin{array}{l}\text { Factor } \\
\text { Loadings }\end{array}$ \\
\hline \multicolumn{2}{|l|}{ Distributive Justice (AVE $=0,85, \mathrm{CR}=0,96, \alpha=0,96$ ) } \\
\hline $\begin{array}{l}\text { DJ1: Although this event caused me problems, this technical service effort to fixit resulted in a } \\
\text { very positive outcome for me. }\end{array}$ & 0.94 \\
\hline DJ2: The outcome I received from this store was fare, given the time and hassle. & 0.96 \\
\hline $\begin{array}{l}\text { DJ3: Given the inconvenience caused by the problem, the outcome I received from this store was } \\
\text { fare. }\end{array}$ & 0.92 \\
\hline \multicolumn{2}{|l|}{ Procedural Justice (AVE=0,79, $\mathrm{CR}=0,93, \alpha=0,93$ ) } \\
\hline PJ1: Despite the hassle caused by the problem, this technical store responded fairly. & 0.90 \\
\hline PJ2: I feel this technical service responded in a timely fashion to the problem. & 0.93 \\
\hline PJ3: I believe this technical service has fair policies and practices to handle problems. & 0.92 \\
\hline $\begin{array}{l}\text { PJ4: With respect to its policies and procedures, this technical service handled the problem in a } \\
\text { fair manner. }\end{array}$ & 0.79 \\
\hline \multicolumn{2}{|l|}{ Interactional Justice (AVE $=0,79, \mathrm{CR}=0,93, \alpha=0,94)$} \\
\hline IJ1: In dealing with my problem, this technical service staff treated me in a courteous manner. & 0.90 \\
\hline $\begin{array}{l}\text { IJ2: During their effort to fix my problem, this technical service staff showed a real interest in } \\
\text { trying to be so fare. }\end{array}$ & 0.90 \\
\hline IJ3: This technical service staff got input from me before handling the problem. & 0.91 \\
\hline IJ4: While attempting to fix my problem, this technical service staff considered my views. & 0.84 \\
\hline \multicolumn{2}{|l|}{ Brand Trust $(\mathrm{AVE}=0,87, \mathrm{CR}=0,95, \alpha=0,96 \quad)$} \\
\hline BT1: I trust this brand. & 0.94 \\
\hline BT2: This brand is honest. & 0.94 \\
\hline BT3: This brand is safe. & 0.92 \\
\hline \multicolumn{2}{|l|}{ Switching Costs $(\mathrm{AVE}=0,88, \mathrm{CR}=0,96, \alpha=0,96)$} \\
\hline SC1: It would cost me a lot of time to change my current brand & 0.94 \\
\hline SC2: It would cost me a lot of effort to change my current brand. & 0.95 \\
\hline SC3: For me it is costly to switch to another brand. & 0.93 \\
\hline
\end{tabular}

\section{Results}

In this section, in the first phase measurement model is evaluated in terms of validity and reliability with confirmatory factor analysis. In the second phase, structural model is developed in order to test the proposed hypotheses.

\subsection{Measurement Model}

In order to measure three exogenous (perceived justice dimensions) and two endogenous constructs (trust, switching costs) a total of 18 items were used. Data were analyzed by two-step approach recommended by Anderson and Gerbing (1988). First, with confirmatory factor analysis measurement model's construct validity, and reliability were evaluated, and then hypotheses were tested by using structural equations modeling. Goodness of fit indexes was evaluated in order to assess the measurement model's adjustments to the obtained data. Confirmatory factor analysis results for overall fit were $\left(\chi^{2} / \mathrm{df}: 257.9 / 125=2.1\right.$, GFI:0.94, AGFI:0.91, CFI:0.98, TLI:0.98, IFI:0.99, RMSEA:0.050) and depicted in Table 2. The confirmatory model's fit indices were acceptable (Arbucle, 2006). In other words, Table 2 reported that, the measurement model fits the sample data 
well. Construct validity of the measurement model was evaluated with convergent validity and discriminant validity. Convergent validity was assessed by examining the standardized factor loadings for the constructs. All factor loadings were significant and above the suggested value of 0.70 (Matzler et al., 2008, p.157.) Therefore, convergent validity was supported.

Table 2. Measurement model results

\begin{tabular}{lccccccc}
\hline $\begin{array}{l}\text { Fit } \\
\text { Statistics }\end{array}$ & $\chi^{2} / \mathrm{df:}$ & GFI & AGFI & CFI & TLI & IFI & RMSEA \\
\hline & $257.9 / 125: 2.1$ & 0.94 & 0.91 & 0.98 & 0.98 & 0.99 & 0.050 \\
\hline
\end{tabular}

Notes: df, degrees of freedom; GFI: Goodness Ft Index; AGFI: Adjusted Goodness Fit Index, CFI: Comparative Fit Index; TLI:Tucker-Lewis Index; IFI: Incremental Fit Index; RMSEA: Root Mean Square Error of Approximation.

In order to achieve discrimant validity, average variance extracted for each construct should exceed the squared correlation between that and other constructs (Fornell and Larckel, 1981). When Table 1 and Table 3 taken into account, AVE's were greater than the squared correlation between the two construct in interest. Thus, discriminant validity of the measurement model was proved.

Table 3. Construct intercorrelations

\begin{tabular}{llllll}
\hline & $(1)$ & $(2)$ & $(3)$ & $(4)$ & $(5)$ \\
\hline 1. Distributive Justice & 1.00 & & & & \\
2. Procedural Justice & 0,77 & 1.00 & & & \\
3. Interactional Justice & 0,78 & 0,75 & 1.00 & & \\
4. Brand Trust & 0,83 & 0,77 & 0,79 & 1.00 & \\
5. Switching Costs & 0,82 & 0,77 & 0,79 & 0,82 & 1.00 \\
\hline
\end{tabular}

In terms of reliability, Cronbach alpha and composite reliability values of the contructs are above the suggested levels of 0.70 and 0.80 respectively (Hair et al., 1998) as depicted in Table 1. In sum, psyhometrisc properties of the measurement model are very good.

\subsection{Structural Model}

After evaluating measurement model, proposed hypotheses were tested with structural equations model using conventional maximum likelihood estimation. The results of the structural model were $\left(\chi^{2} / \mathrm{df}: 257.9 / 125=2.1\right.$, GFI:0.94, AGFI:0.91, CFI:0.98, TLI:0.98, IFI:0.99, RMSEA:0.050). Therefore, the hypothesized structural model yielded good fit. According to the squared multiple correlations, the model explained $76 \%$ of the variance in brand trust and $77 \%$ in switching costs. Thus, substantial proportion of variance in brand trust and switching costs are explained. The results of the structural model are presented in Figure 2.

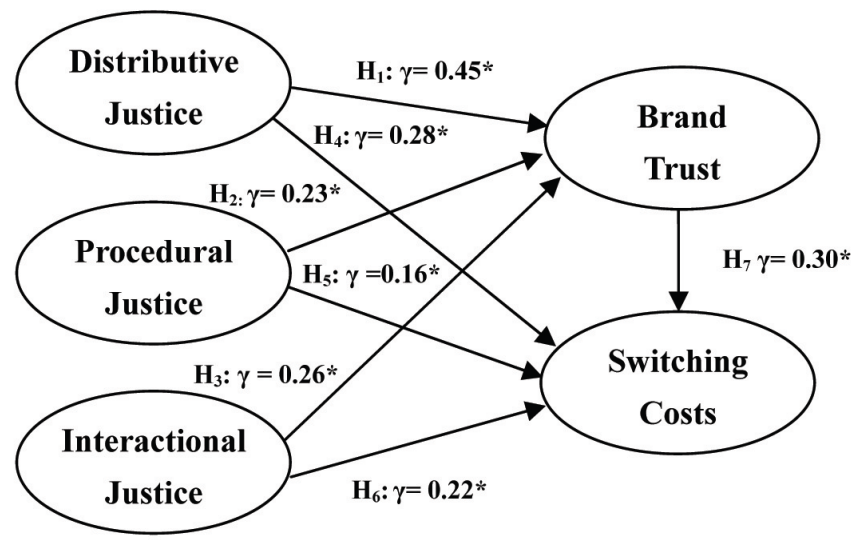

Figure 2. Structural model results

\section{Fit Statistics:}

$\chi^{2} / \mathrm{df}: 257.9 / 125=2.1$

GFI:0.94, AGFI:0,91

CFI:0.99, TLI:0,98

IFI:0.99, RMSEA:0.050

${ }^{*} p<0,001$ 
According to the Figure 2, distributive justice has positive effect on brand trust and switching costs, supporting hypothesis $1(\gamma=0.45, \mathrm{p}<0,001)$ and hypothesis $4(\gamma=0.28, \mathrm{p}<0,001)$. Consistent with hypothesis 3 and hypothesis 6 , interactional justice positively affects brand trust $(\gamma=0.26, p<0,001)$ and switching costs $(\gamma=0.22, p<0,001)$ respectively. In addition, structural model demonsrated that, procedural justice is positively related to brand trust and switching costs, supporting to hypothesis $2(\gamma=0.23, \mathrm{p}<0,001)$ and hypothesis $5(\gamma=0.16, \mathrm{p}<0,001)$. The results of the structural model also revealed that brand trust is an antecedent of switching costs supporting to hypothesis $7(\beta=030, p<0,001)$. Thus, the results of seven hypotheses demonstrate that, positive percepitions of distributive and interactional and procedural justice significantly enhance brand trust and consequently switching costs. In addition, distributional just justice displayed the greatest impact on both brand trust and switching costs among other justice dimensions.

\section{Implications}

Due to the fierce competition in the marketplace, customers' evaluations towards brands are vital for businesses in order to achive competitive advantage. In this context one of the weapons for businesse to differentiate themselves among competitiors is implementing successful complaint handling process. Based on this argument, the objective of this study was to understand the effects of perceived justice on brand trust and switching costs. The results of the structural model demonstrated that all proposed hypotheses were supported. Thus, the results revaled positive relationship between perceived justice and brand trust supporting to results of the past reserach (Dewitt et al., 2008; dos Santos and Fernandes, 2008). Findings also indicated positive relationship between perceived justice and switching costs. Moreover, results demonstrated that brand trust is positively related to switching costs. In other words, fair service recoveries will not only help to build brand trust but are also having direct impact on switching costs. Thus, companies should effort to offer fair outcomes, procedures, and personal interactions (Maxham III \& Netemeyer, 2002, p. 248).

In particular, the results of this study revealed that distributive justice is a key entecedent of brand trust and switching costs. This implies that, offering mainly fair redress including refunds, discounts and product replacements can likely increase brand trust and consequently enhance switching costs. This implies that, offering mainly fair redress including refunds, discounts and product replacements can likely increase brand trust and consequently enhance switching costs. As such in durable good industries where repurchases are less frequent, relationships are long-term and recommendations are vital, the results of this study proved that it is beneficial for retail stores to offer proportionately more distributive justice (Maxham III \& Netemeyer 2002, p. 248). It should be emphasizing that the fundamental aim of service recovery is not only retaining cutomers but also maintain long-term relationships and in this context building trust is crucial (Kim et al., 2011; p.61; Delgado-Ballester \& Munuera-Alemán, 2005, p.193). In other words, the success in complaint handling provides support to relationship marketing and in this context, complaint data provides opportunity to demonstrate firms' trustworthiness and success in complaint handling process determines customers' future relationships with a firm (Tax et al., 1998, p.72). Trust has been considered a vital prerequisite of maintaining the relationship between company and customer (Delgado-Ballester \& Munuera-Alemán, 2005, p.189).

The results of the study also suggested that retailers offering procedural and interactional justice following failures may also increase brand trust and subsequently enhance switching costs. Thus, in ongoing service relationships where retaining current customers is vital for achieving competitive advantage, fair policies and procedures, as well as respectful employee interactions, (Maxham III \& Netemeyer, 2002, p.248) may positively influence customer perceptions of brand trust and switching costs In this context, store employees or managers should act polite, respectful, and insightful and emphatetic manner when resolving customer problems thus, this kind of behaviors will help to diffuse complaint customers' anger during the complaint resolution process (Tax et al., 1998, p.72). In addition, company should observe the aspects of interactional justice including the courtesy, emphaty, symphaty, apology, respectful and fair relationships with customers in the complaint handling resolution (dos Santos \& Fernandes, 2008, p. 108; Kim et al., 2011, p.61; Blodget et al., 1997, p.202; Smith et al., 1999, p.369) and take precautions in order to prevent from failures (Kim et al., 2011, p.61). In order to provide fair treatment employees' job descriptions should be accurately planned (Tax et al., 1998, p.72). Retailers should train customers how to solve the problems about products and services, how to respond complaints with courtesy and respect in a timely manner and to give the customer and opportunity to explain the customer in extraordinary situations (Blodget et al., 1997, p.202; Tax et al., 1998, p.72; Kim et al. 2009, p.61). In this context trainin programs may contribute success of the business (dos Santos and Fernandes, 2008, p.108). Moreover, in order to motive parsonell to solve the problems empoverment (Kim et al. 2011, p. 61) and rewarding is another issue that should be considered (Maxham III, 1999, p.21).

Procedural fairness can be achieved with fast and easily accessable amd consistent call centers with specialists 
dealing with product or service complaints (Tax et al., 1998, p.72). Maxham III (1999, p.21) pointed out that, developing service recovery teams, firms may respond quicker and more efficient to product or service failures. Service guarantees can also be used to provide consistent and efficient processing of complaint (Tax et al., 1998, p.72). In addition, both employee and customer feedback and comments should also be used in order to revise complaint handling process (Maxham III \& Netemeyer, 2003, p.58; Dewitt et al., 2007, p.269; Smith et al., 1999, p.369). Moreover, fair interactions and procedures, can lower the cost of complaining and thereby reduce the compensation required to achieve distributive justice (Tax et al. 1998, p.73).

Brands can differentiate among competitiors with providing effective, well structured and valuable communication with customers in the stores with company staff and this may support brand trust and (Ball et al., 2004, p.1284; Delgado-Ballester \& Munuera-Alemán, 2005, p.193) and consequently enchance switching costs. Moreover, in the the context of relationship marketing, offering customers useful advice and information about products and services, firms can provide additional value to customers and as a result this may lead competitive advantage (Ball et al., 2004, p.1284). Brand trust can also be used as an opportunity for brand extensions (Delgado-Ballester and Munuera-Alemán, 2005, p.187). In other words, firms can benefit from their trusted brands in order to extent their brands to new products categories (Reast, 2005, p.9).

Another issue that should be considered about comnplaint handling success is the promises of the companies about products and services (Delgado-Ballester \& Munuera-Alemán, 2005, p.193). In this context, unrealistic promises about compliant handling process may cause higher expectations and therefore, they will be more likely disappointed about the given redress. Thus, companies should define their promises and keep consistently in all complaint resolutions (Delgado-Ballester and Munuera-Alemán, 2005, p.193). The success of the fulfillment of the promises about complaints may also support to build brand trust.

The results of this study also demonstrated positive relationship between brand trust and switching costs supporting the results of the previous studies (Yen et al., 2011; Konuk \& Konuk, 2012). In line with this finding, it is infeered that unsuccseesful service recoveries may lead customers switch their current service provider, thus recruiting new customers will bring extra costs for the company (Maxham III, 1999, p.21). In this context, brand trust can be use to retain current customers by increasing switching costs. In other words, when service firms fail to manage customers' complaints successfully, their customers unavoidably switch to another service firm (Kim et al., 2011, p. 60). As a result, service recovert efforts should be carewfully planned in order to maintain relationships between customers and a firm (Kim et al. 2011, p. 60). Providing only sufficient compensation is not enough to build brand trust and switching costs, thus offering fair policies and interactions should also be considered in tems of company success (dos Santos \& Fernandes 2008, p.108; Smith et al., 1999, p.369). As a results, service providers should provide fair service recovery in order to build brand trust and thereby retain their current customers by increasing switching costs in order to achieve competitive advantage in the marketplace.

\section{Limitations and Future Research}

The convenience sample of complaining customers towards white goods investigated in this study is not representative of the whole population of customers. Therefore, it is difficult to generalize the results. In order to obtain more representative results, future research should be conducted with other durable product or service categories in different cities. In this study, cross-sectional research design was used. Therefore, longitudinal field studies would be beneficial in terms of exaimining the relationships between the contructs over time.

With future studies, proportion of variance explained in brand trust and switching costs could be improved by including other brand trust antecedents such as satisfaction, quality, and perceived value in the comprehensive models. In other words, predictability of brand trust and switching costs could be increase by exploring other antecedents of these concepts. It is also worth noting to broaden our understanding the relationships between perceived justice and brand image and perceived value and perceived risk in a complaint handling context. In addition, future research dealing with perceived justice, consequences of brand trust and switching costs including, word-of-mouth intentions, loyalty and willingness to pay should be incorporated in more detailed integrated framework.

\section{References}

Anderson, J. C., \& Gerbing, D. W. (1998). Structural equation modeling in practice: A review and recommended two-step approach. Psychological Bulletin, 103(3), 411-423. http://dx.doi.org/10.1037/0033-2909.103.3.411

Arbuckle, J. L. (2006). Amos 7.0 User's Guide. PA, USA.

Ball, D., Coelho, P. S., \& Machás, A. (2004). The role of communication and trust in explaining customer loyalty: 
An extension to the ECSI model. European Journal of Marketing, 38(9/10), 1272-1293. http://dx.doi.org/10.1108/03090560410548979

Beerli, A., Martin, J. D., \& Quintana, A. (2004). A model of customer loyalty in the banking market. European Journal of Marketing, 38(1), 253-275. http://dx.doi.org/10.1108/03090560410511221

Blodgett, J., Hill, D. J., \& Tax, S. S. (1997). The effects of distributive, procedural and interactional justice on $\begin{array}{llll}\text { post-complaint behavior. Journal of Retailing, } & \text { 73(2), }\end{array}$ http://dx.doi.org/10.1016/S0022-4359(97)90003-8

Brown, T., Barry, T. E., Dacin, P. A., \& Gunst, R. F. (2005). Spreading the word: Investigating antecedents of consumers' positive word-of-mouth intentions and behaviors in a retailing context. Journal of the Academy of Marketing Science, 33(2), 123-138. http://dx.doi.org/10.1177/0092070304268417

Chaudhuri, A., \& Holbrook, M. B. (2001). The chain of effects from brand trust and brand affect to brand performance: The role of brand loyalty. Journal of Marketing, 65, 81-93. http://dx.doi.org/10.1509/jmkg.65.2.81.18255

Chiou, J., \& Droge, C. (2006). Service quality, trust, specific asset investment, and expertise: Direct and indirect effects in a satisfaction-loyalty framework. Journal of the Academy of Marketing Science, 3(4), 613-627. http://dx.doi.org/10.1177/0092070306286934

de Matos, C. A., Rossi, C. A. V., Veiga, R. T., \& Veira, V. A. (2009). Consumer reaction to service failure and recovery: The moderating role of attitude toward complaining. Journal of Service Marketing, 23(7), 462-475. http://dx.doi.org/10.1108/08876040910995257

del Rio-Lanza, A. B., Vazquez-Casielles, R., \& Diaz-Martin, A. M. (2009). Satisfaction with service recovery: Perceived justice and em otional responses. Journal of Business Research, 62(8), 775-781. http://dx.doi.org/10.1016/j.jbusres.2008.09.015

Delgado-Ballester, E., \& Munuera-Alemán, J. L. (2005). Does brand trust matter to brand equity. Journal of Product \& Brand Management, 14(3), 187-196. http://dx.doi.org/10.1108/10610420510601058

DeWitt, T., Nguyen, D. T., \& Marshall, R. (2008). Exploring Customer Loyalty Following Service Recovery: The mediating effects of trust and emotions. Journal of Service Research, 10, 269-281. http://dx.doi.org/10.1177/1094670507310767

dos Santos, C. P., \& Fernandes, D. V. H. (2008). Antecedents and consequences of consumer trust in the context of service recovery. Brazilian Administrative Review, 5(3), 225-244. http://dx.doi.org/10.1590/S1807-76922008000300005

Edward, M., George, B. P., \& Sarkar, S. K. (2012). The impact of switching costs upon the service quality-perceived value-customer satisfaction-service loyalty chain: A study in the context of cellular services in India. Services Marketing Quarterly, 31(2), 151-173. http://dx.doi.org/10.1080/15332961003604329

Fornell, C., \& Larcker, D. F. (1981). Evaluating structural equation models with unobservable variables and measurement Errors. Journal of Marketing Research, 18, 39-50. http://dx.doi.org/10.2307/3151312

Fuentes-Blasco, M., Saura, I., \& Berenguer-Contri, G. (2010). Measuring the antecedents of e-lotalty and the effect of switching costs on website. The Service Industries Journal, 30(11), 1837-1852. http://dx.doi.org/10.1080/02642060802626774

Hair, J. F., Anderson, R. E., Tahtam, R. L., \& Black, W. J. (1998). Multivariate Data Analysis (5th ed.). New Jersey: Prentice Hall.

Hart, C. W. L., Heskett, J. L., \& Sasser, W. E. J. (1990). The profitable art of service recovery. Harvard Business Review, 68(4), 148-156.

Homburg, C., \& Fürst, A. (2005). How organizational complaint handling drives customer loyalty: An analysis of the mechanistic and the organic approach. The Journal of Marketing, 69(3), 95-114. http://dx.doi.org/10.1509/jmkg.69.3.95.66367

Hui, M. K., \& Au, K. (2001). Justice perceptions of complaint-handling: A cross-cultural comparison between PRC and Canadian customers. Journal of Business Research, 52(2), 161-173. http://dx.doi.org/10.1509/10.1016/S0148-2963(99)00068-5

Johnson, R. (2001). Linking complaint management to profit. International Journal of Sevice Industry 
Management, 12(1), 60-69. http://dx.doi.org/10.1108/09564230110382772

Jones, M., Mothersbaugh, D., \& Baetty, S. (2000). Switching barriers and repurchase intentions in services. Journal of Retailing, 76(2), 259-274. http://dx.doi.org/10.1016/S0022-4359(00)00024-5

Kau, A., \& Loh, E. W. (2006). The effects of service recovery on consumer satisfaction: A comparison between complainants and non-complainants. Journal of Services Marketing, 20(2), 101-111. http://dx.doi.org/10.1108/08876040610657039

Keaveney, S. M. (1995). Customer switching behavior in service industries: An exploratory study. Journal of Marketing, 59(2). http://dx.doi.org/71-83. 10.2307/1252074

Kim, T. T., Kim, W. G., \& Kim, H. (2009). The Effects of perceived justice on recovery satisfaction, trust, word-of-mouth, and revisit intention in upscale hotel. Tourism Management, 30(1), 51-62. http://dx.doi.org/10.1016/j.tourman.2008.04.003

Konuk, F. A., \& Konuk, F. (2012). The Relationship between service quality, economic and switching costs in retail banking. Business Systems Review, 2(1), 1-16. http://dx.doi.org/10.7350/BSR.B01.2013

Lam, S. Y., Shankar, V., Erramilli, M. K., \& Murthy, B. (2004). Customer value, satisfaction, loyalty, and switching costs: An illustration from a business-to-business service context. Journal of the Academy of Marketing Science, 32(3), 293-311. http://dx.doi.org/10.1177/0092070304263330

Lee, J., \& Feick, L. (2001). The impact of switching costs on the customer satisfaction-loyalty link: Mobile phone service in France. Journal of Services Marketing, 15(1), 35-48. http://dx.doi.org/10.1108/08876040110381463

Matzler, K., Sonja Grabner-Kräuter, S., \& Bidmon, S. (2008). Risk aversion and brand loyalty: the mediating role of brand trust and brand affect. Journal of Product \& Brand Management, 17(3), 154-162. http://dx.doi.org/10.1108/10610420810875070

Maxham III, J. G. (2001). Service recovery's influence on cosumer satisfaction, positive word-of-mouth and purchase intentions. Journal of Business Research, 54, 11-24. http://dx.doi.org/10.1016/S0148-2963(00)00114-4

Maxham III, J. G., \& Netemeyer, R. G. (2002). Modeling customer perceptions of complaint handling over time: The effects of perceived justice on satisfaction and intent. Journal of Retailing, 78, 239-252. http://dx.doi.org/10.1016/S0022-4359(02)00100-8

Moorman, C., Deshpandé, R., \& Zaltman, G. (1993). Factors affecting trust in market research relationships. Journal of Marketing, 57, 81-101. http://dx.doi.org/10.2307/1252059

Morgan, R. M., \& Hunt, S. D. (1994). The commitment-trust theory of relationship marketing. Journal of Marketing, 58, 20-38. http://dx.doi.org/10.2307/1252308

Ranaweera, C., \& Prabhu, J. (2003). The influence of satisfaction, trust and switching barriers on customer retention in a continuous purchases setting. International Journal of Service Industry Management, 14(4), 374-395. http://dx.doi.org/10.1108/09564230310489231

Reast, J. D. (2005). Brand trust and brand extension acceptance: The relationship. Journal of Product \& Brand Management, 14(1), 4-13. http://dx.doi.org/10.1108/10610420510583707

Reichheld, F. F., \& Sasser, W. E. (1990), Zero defections: Quality comes to services. Harvard Business Review, September-October, 105-111.

Schoefer, K., \& Ennew, C. (2005). The Impact of perceived justice on consumers' emotional responses to service complaint experiences. Journal of Services Marketing, 19(5), 261-270. http://dx.doi.org/10.1108/08876040510609880

Smith, A. K., Bolton, R. N., \& Wagner, J. (1999). A model of customer satisfaction with Service encounters involving failure and recovery. Journal of Marketing Research, 36(3), 356-372. http://dx.doi.org/10.2307/3152082

Tax, S. S., Brown, S. W., \& Chandrashekaran, M. (1998). Customer evaluations of service complaint experiences: implications for relationship marketing. Journal of Marketing, 62(2), 60-76. http://dx.doi.org/10.2307/1252161

Tung, G., Kuo, C., \& Kuo, Y. (2011). Promotion, switching barriers, and loyalty. Australian Journal of Business and Management Research, 1(2), 30-44. 
Wong, C. B. (2011). The Influence of customer satisfaction and switching costs on customer retention: retail internet banking services. Global Economy and Finance Journal, 4(1), 1-18.

Yang, P., \& Peterson, R. T. (2004). Customer perceived value, satisfaction, and loyalty: The Role of Switching Costs. Psychology \& Marketing, 21(10), 799-822. http://dx.doi.org/10.1002/mar.20030

Yen, Y., Wang, E., \& Horng, D. (2011). Suppliers' willingness of customization, effective communication, and trust: A study of switching costs antecedents. Journal of Business \& Industrial Marketing, 26(4), 250-259. http://dx.doi.org/10.1108/08858621111126992 